\title{
Evaluasi kualitas finishing water and solvent based yang diaplikasikan pada kayu lapis
}

\section{Evaluation of water and solvent based finishing performance applied to plywood}

\author{
Arip Wijayanto ${ }^{\mathrm{a}, \star}$, Nurmadina ${ }^{\mathrm{a}}$, Didik Wasono $^{\mathrm{b}}$, Izza Afkarina $^{\mathrm{a}}$ \\ ${ }^{a}$ Politeknik Industri Furnitur dan Pengolahan Kayu, BPSDMI, Kementerian Perindustrian \\ Jalan Wanamarta Raya, No.20, Kawasan Industri Kendal, Kendal, Indonesia \\ ${ }^{\mathrm{b}}$ Bioindustries \\ Jalan Sidikan 94, Sorosutan, Yogyakarta, Indonesia \\ *wijayanto.arip@gmail.com
}

Diterima 23 Februari 2021 Direvisi 05 Mei 2021 Disetujui 10 Desember 2021

\begin{abstract}
ABSTRAK
Peningkatan tampilan dari produk furnitur berbahan dasar kayu lapis dapat dilakukan dengan melakukan proses finishing. Sementara itu, kualitas hasil finishing sangat dipengaruhi oleh bahan finishing yang digunakan. Penelitian ini bertujuan untuk mengetahui sifat finishing dari kayu lapis yang diberi perlakuan bahan finishing water based dan solvent based (Poliuretan, Nitroselulosa, dan Melamin). Pertama, kayu lapis vinir jati berukuran $30 \mathrm{~cm} \times 30 \mathrm{~cm} \times 0,6 \mathrm{~cm}$ disiapkan permukaannya dengan menggunakan ampelas P 240. Kemudian diaplikasikan sanding sealer dan top coat untuk masing-masing jenis bahan finishing pada permukaan kayu lapis dan dilakukan pengujian. Pengujian nilai kilap dilakukan dengan menggunakan alat gloss meter, pengujian daya lekat lapisan finishing mengacu pada ASTM D 3359, pengujian fleksibilitas dilakukan dengan coin test, pengujian kekerasan mengacu pada ASTM D 3363, ketahanan lapisan finishing terhadap panas-dingin dan bahan kimia rumah tangga (kecap dan saos) mengacu pada ASTM D 1654. Masing-masing pengujian dilakukan sebanyak tiga kali ulangan dan diolah datanya menggunakan Microsoft excel serta SPSS.19. Hasil pengujian menunjukkan bahwa nilai kilap lapisan finishing water based, melamin, dan nitroselulosa termasuk dalam kategori semi gloss (40-60)\%, sedangkan lapisan finishing poliuretan termasuk kategori gloss (60-80)\%. Sementara itu, daya lekat lapisan finishing water based memilki daya lekat yang paling tinggi, diikuti poliuretan, melamin, dan nitroselulosa. Hasil pengujian fleksibilitas menunjukkan bahwa lapisan finishing water based dan poliuretan memiliki fleksibilitas sangat baik sedangkan nitroselulosa dan melamin termasuk kategori cukup. Selanjutnya, berdasarkan kekerasannya maka lapisan finishing poliuretan memiliki tingkat kekerasan yang paling tinggi $(6 \mathrm{H})$ diikuti lapisan finishing, melamin dan nitroselulosa $(5 \mathrm{H})$, sedangkan lapisan finishing water based merupakan yang paling lunak $(2 \mathrm{H})$. Pengujian ketahanan lapisan finishing terhadap panas-dingin dan bahan kimia rumah tangga menunjukkan hasil yang sama untuk semua lapisan finishing, yaitu masuk ke dalam kelas 10. Berdasarkan seluruh hasil pengujian bahan finishing yang memiliki kualitas paling bagus untuk diterapkan pada kayu lapis adalah jenis poliuretan.
\end{abstract}

Kata Kunci: finishing; kayu lapis; kualitas; solvent based; water based

\section{ABSTRACT}

The appearance of furniture products using plywood as raw material can be improved by finishing. The quality of finishing is greatly influenced by the finishing materials. The aim of this study was to determine performances of plywood coated by water and solvent based (polyurethane, nitrocellulose, and melamine) paints. The surface of teak veneer plywood $(30 \mathrm{~cm} \times 30 \mathrm{~cm} \times 0,6 \mathrm{~cm})$ was prepared using $P 240$ sandpaper. Then sanding sealer and top coat of each finishing material were applied to the plywood. Finishing properties was evaluated by using glossy test that carried out by gloss meter, 
cross cut test based on ASTM D3359, pencil hardness based on ASTM D3363, surface resistance against hot and cold also household chemical test based on ASTM D1654 and coin test to evaluate surface flexibelity. Each test was repeated three times and the data was processed using microsoft excel and SPSS.19. The gloss value of water based, nitrocellulose, and melamine could be categorized as semi gloss (40-60)\%, while polyurethane could be categorized as gloss (60-80)\%. The water based had the highest adhesion strength followed by polyurethane, melamine, and nitrocellulose. The water based and polyurethane had very good flexibility, while nitrocellulose and melamine were in the sufficient category. Polyurethane had the highest hardness level (6H) followed by melamine and nitrocellulose $(5 \mathrm{H})$, while water based finishing layer was the softest $(2 \mathrm{H})$. The resistance of all finishing layers against hot-cold and household chemicals were included in class 10. Based on the results of the test, polyurethane finishing applied to plywood had the best performance.

\section{Keywords: finishing; performance; plywood; solvent based; water based}

\section{PENDAHULUAN}

Penerapan "Making Indonesia 4.0" di tahun 2018 diharapkan mampu memacu Indonesia untuk menjadi bagian dari 10 negara dengan perekonomian terbesar di dunia pada tahun 2030. Kementerian Perindustrian memacu sektor industri untuk mengimplementasikan industri 4.0 pada proses industrinya. Salah satu sektor industri yang berpeluang untuk ditingkatkan produktivitasnya adalah industri furnitur. Industri tersebut ditunjang dengan ketersediaan bahan baku yang cukup melimpah, baik itu kayu solid maupun kayu olahan seperti kayu lapis. Menurut Munadi \& Salim (2017), terdapat dua kelompok industri pengolahan kayu hilir, yaitu kayu solid dan plywood (kayu lapis), termasuk block board, medium density fibreboard (MDF), dan papan partikel. Penggunaan kayu olahan seperti kayu lapis pada pembuatan furnitur saat ini telah banyak dilakukan terutama oleh perusahaan besar. Biasanya industri furnitur mengkombinasikan penggunaan kayu solid dengan kayu olahan/kayu lapis pada produk furnitur yang dihasilkan. Pada tahun 2017, produksi kayu lapis mencapai 6,17 juta $\mathrm{m}^{3}$ (BPS, 2018).

Upaya peningkatan daya jual produk furnitur dapat dilakukan dengan meningkatkan kuantitas dan kualitas produk furnitur. Selain itu, perlu adanya peningkatan tampilan dari produk furnitur yang dihasilkan. Pada industri furnitur, permukaan produk dari kayu ataupun kayu olahan umumnya akan diberi perlakuan proses finishing untuk meningkatkan tampilannya. Finishing pada kayu olahan seperti kayu lapis dapat dilakukan dengan cat kayu, vinir, dan paper laminate (Munadi \& Salim, 2017).

Kualitas hasil finishing sangat dipengaruhi oleh beberapa faktor, diantaranya adalah kualitas permukaan substrat dan jenis bahan finishing yang digunakan (Ramananantoandro, Eyma, Belloncle, Rince, \& Irle, 2018; Salca, Krystofiak, \& Lis, 2017). Pada penelitian sebelumnya, telah dilaporkan beberapa kayu lapis dari kelapa sawit yang difinishing menggunakan nitroselulosa, precatalyzed lacquer dan poliuretan. Hasil pengujian daya lekat lapisan finishing pada penelitian tersebut dilaporkan bahwa kayu lapis dari kelapa sawit memiliki nilai yang bagus jika dibandingkan dengan kayu jenis meranti (Sulaiman, Hashim, Wahab, Samsi, \& Mohamed, 2008). Penggunaan poliuretan sebagai bahan finishing juga telah diaplikasikan pada kayu kelapa, hasilnya menunjukkan bahwa lapisan finishing tersebut memiliki daya rekat $90 \%$ $100 \%$ (Purwanto, 2011). Penelitian lainnya melaporkan bahwa kualitas permukaan yang dihasilkan dari lapisan finishing water based maupun solvent based pada dua jenis substrat yang berbeda yaitu vinir dan kayu gergajian menunjukkan perbedaan yang sangat kecil (Véronic, Blanchet, \& Cormier, 2013). Sementara itu, pengujian kekerasan lapisan finishing dengan metode pencil hardness pernah digunakan pada penelitian sebelumnya, yaitu untuk 
pengujian lapisan finishing epoxy acrylate pada wooden furniture yang dilapisi fancy veneer plywood. Hasilnya tidak menujukkan perbedaan yang signifikan dengan dua metode lain yang digunakan, yaitu pendulum hardness dan microhardness (Choi \& Kim, 2006).

Penelitian secara komprehensif terkait sifat-sifat finishing pada kayu lapis dengan perlakuan berbagai macam jenis bahan finishing saat ini masih belum dilakukan. Oleh karena itu, penelitian ini bertujuan untuk membandingkan sifat-sifat finishing dari bahan finishing water based (WB), poliuretan (PU), nitroselulosa (NC), dan melamin (MM) yang diaplikasikan dengan teknik semprot pada substrat kayu lapis. Sifat finishing yang diamati diantaranya adalah nilai kilap (glossy test), daya lekat lapisan finishing (cross cut test), fleksibilitas (coin test), kekerasan (pencil hardness), ketahanan lapisan finishing terhadap panas-dingin, dan ketahanan lapisan finishing terhadap bahan kimia rumah tangga (kecap dan saos).

\section{BAHAN DAN METODE}

\subsection{Bahan}

Bahan yang digunakan pada penelitian ini adalah kayu lapis vinir jati dengan ketebalan $0.6 \mathrm{~cm}$, bahan-bahan finishing poliuretan (PU), melamin (MM), dan nitroselulosa (NC) yang digunakan berupa sanding sealer, dan top coat gloss merk propan dan bahan finishing water based (WB) berupa sanding sealer, dan top coat gloss merk bioindustri. Untuk pengujian finishing, bahan yang dibutuhkan diantaranya air panas, es batu, kecap dan saos merk indofood. Alat yang digunakan berupa ampelas 240 dan 400 merk ekamant, spry gun, gloss meter 3nh YG60S 60, satu set pensil merk staedtler mars lumograph, koin, dan peralatan pengujian cross cut, seperti cutter serta pressure tape.

\subsection{Metode}

\subsubsection{Persiapan Contoh Uji}

Pengaplikasian

bahan-bahan finishing menggunakan tahapan yang sama untuk setiap perlakuan. Tahap pertama adalah persiapan permukaan substrat lapisan finishing dengan melakukan pengampelasan menggunakan ampelas $P$ 240. Setelah itu, campuran sanding sealer dan air (2:1) diaplikasikan menggunakan spray gun pada seluruh permukaan. Pengaplikasian sanding sealer dilakukan sebanyak dua kali dan untuk masing-masing pengaplikasian diakhiri dengan pengampelasan menggunakan ampelas $P$ 400. Tahap terakhir adalah pengaplikasian top coat menggunakan spray gun. Untuk finishing WB menggunakan campuran top coat dan air (2:1), sedangkan untuk finishing NC, PU, dan MM menggunakan campuran top coat masing-masing bahan finishing dengan thinner (1:1).

\subsubsection{Pengujian}

a. Pengujian nilai kilap (glossy test)

Pengujian nilai kilap dilakukan dengan menggunakan alat gloss meter $3 \mathrm{nh}$ YG60S 60 yang ditempelkan pada permukaan contoh uji. Kemudian hasil pengujian (\%) didapatkan dengan pembacaan langsung pada alat gloss meter tersebut. Hasil pengujian dikelompokkan berdasarkan parameter yang digunakan oleh Bioindustries (2017) sebagaimana Tabel 1 berikut.

Tabel 1. Klasifikasi Pengujian Nilai Kilap

\begin{tabular}{ll}
\hline Jenis & Nilai kilap \\
\hline Death matte & $0-10 \%$ \\
\hline Matte & $10-20 \%$ \\
\hline Doff & $20-30 \%$ \\
\hline Satin & $30-40 \%$ \\
\hline Semi gloss & $40-60 \%$ \\
\hline Gloss & $60-80 \%$ \\
\hline High Gloss & $80-100 \%$ \\
\hline Mirror & $>100 \%$ \\
\hline Sumber: Bioindustries $(2017)$
\end{tabular}

\section{b. Pengujian daya lekat lapisan finishing} (cross cut test)

Pengujian daya lekat lapisan finishing dilakukan sesuai dengan ASTM D 3359. Parameter yang diamati adalah banyaknya potongan kisi selotip yang mengelupas atau terangkat dari permukaan contoh uji. Penilaian dilakukan berdasarkan besarnya 
Tabel 2. Parameter Fleksibilitas dan Daya Lekat Lapisan Finishing pada Permukaan Kayu

\begin{tabular}{llll}
\hline Nilai & Keterangan & $\begin{array}{l}\text { Parameter pengamatan pengujian } \\
\text { fleksibelitas }\end{array}$ & $\begin{array}{l}\text { Parameter pengamatan pengujian } \\
\text { daya lekat }\end{array}$ \\
\hline 5 & $\begin{array}{l}\text { Sangat } \\
\text { Bagus }\end{array}$ & $\begin{array}{l}\text { Tidak berwarna putih dan sangat } \\
\text { fleksibel dengan tanda tidak } \\
\text { berbunyi getas sewaktu digores }\end{array}$ & $\begin{array}{l}\text { Sisi lapisan cat yang digores sangat } \\
\text { halus dan tidak ada lapisan yang } \\
\text { mengelupas }\end{array}$ \\
\hline 4 & Baik & $\begin{array}{l}\text { Tidak berwarna puth dan cukup } \\
\text { fleksibel, bunyi yang ditimbulkan } \\
\text { sangat pelan dan cenderung } \\
\text { kenyal }\end{array}$ & $\begin{array}{l}\text { Ada keretakan kecil pada bekas } \\
\text { sayatan cutter dan kerusakan lapisan } \\
<5 \%\end{array}$ \\
\hline 3 & Cukup & $\begin{array}{l}\text { Sedikit berwarna putih dan cukup } \\
\text { berbunyi saat digores }\end{array}$ & $\begin{array}{l}\text { Kerusakan di sepanjang sayatan dan } \\
\text { di dalam kotak sayatan, kerusakan } \\
\text { lapisan 5\% s.d. 15\% }\end{array}$ \\
\hline 2 & Kurang & $\begin{array}{l}\text { Timbul warna putih dan cukup } \\
\text { berbunyi saat digores }\end{array}$ & $\begin{array}{l}\text { Kerusakan di sepanjang sayatan dan } \\
\text { beberapa kotak terlepas, kerusakan } \\
\text { lapisan 15\% s.d. 35\% }\end{array}$ \\
\hline 1 & Jelek & $\begin{array}{l}\text { Lapisan hancur berkeping-keping } \\
\text { serusakan di seluruh bekas sayatan } \\
\text { terjadi hampir di seluruh kotak, } \\
\text { kerusakan lapisan }>65 \%\end{array}$ \\
\hline
\end{tabular}

Sumber: ASTM D 3359 dan Prayitno, Ayu, \& Sari, (2013)

persentase lapisan finishing yang mengelupas dan kemudian dikategorikan seperti Tabel 2.

\section{c. Pengujian Fleksibilitas (coin test)}

Coin test dilakukan untuk mengetahui fleksibilitas atau kegetasan suatu bahan finishing terhadap substrat ataupun lapisan cat di bawahnya. Pengujian ini dilakukan dengan mengacu pada metode coin test yang digunakan oleh penelitian (Prayitno et al., 2013), kemudian hasil pengujian dikelompokkan sesuai dengan Tabel 2.

\section{d. Pengujian kekerasan (pencil hardness) \\ Pengujian pencil hardness mengacu} pada ASTM D3363, yaitu menggunakan pensil dengan kekerasan berbeda dari 6B s.d. $6 \mathrm{H}$. Merk pensil yang digunakan pada penelitian ini adalah staedtler mars lumograph. Pengukuran kekerasan lapisan finishing dimulai dengan menggunakan pensil yang paling keras dan terus menurun untuk menentukan kekerasan minimum yang mampu menggores permukaan lapisan finishing. Goresan pada lapisan finishing dilakukan secara konstan pada sudut $45^{\circ}$ dari permukaan lapisan finishing.

\section{e. Pengujian ketahanan terhadap panas dingin}

Uji ketahanan terhadap panas dilakukan dengan cara meletakkan gelas kecil berisi air panas (mendidih) yang didiamkan sampai air dalam gelas menjadi dingin. Sedangkan pengujian dingin dilakukan dengan meletakkan es batu dalam gelas di atas permukaan uji, kemudian ditunggu sampai seluruh es mencair. Setelah itu dilakukan pengamatan terhadap permukaan contoh uji dan diklasifikasikan sesuai dengan ASTM D 1654 seperti pada Tabel 3.

Tabel 3. Klasifikasi Nilai Kondisi Cacat Permukaan

\begin{tabular}{lc}
\hline $\begin{array}{l}\text { Presentase permukaan } \\
\text { bercacat }(\%)\end{array}$ & Kelas \\
\hline Tidak bercacat & 10 \\
\hline $0-1$ & 9 \\
\hline $2-3$ & 8 \\
\hline $4-7$ & 7 \\
\hline $7-10$ & 6 \\
\hline $11-20$ & 5 \\
\hline $21-30$ & 4 \\
\hline $31-40$ & 3 \\
\hline $41-55$ & 2 \\
\hline $56-75$ & 1 \\
\hline$>75$ & 0 \\
\hline
\end{tabular}

Sumber: ASTM D 1654 
f. Pengujian ketahanan terhadap bahan kimia rumah tangga

Pengujian Daya Tahan Lapisan Terhadap Bahan Kimia Rumah Tangga dilakukan dengan menggunakan bahan kimia rumah tangga kecap dan saos yang dioleskan pada permukaan contoh uji lalu didiamkan selama 5-10 menit. Sebelum dilakukan pengujian, contoh uji dikeringudarakan terlebih dahulu selama 1 minggu untuk menghindari terjadinya perubahan kecerahan dan kekerasan pada lapisan finishing. Setelah pengujian kemudian dilakukan pengamatan terhadap permukaan contoh uji dan diklasifikasikan seperti pada Tabel 3.

\subsubsection{Pengolahan Data}

Pengujian pada kayu lapis dengan perlakuan berbagai jenis bahan finishing dilakukan dengan tiga kali ulangan. Kemudian data yang diperoleh diolah menggunakan microsoft excel. Kemudian untuk hasil pengujian nilai kilap dan daya lekat lapisan finishing dianalisis menggunakan rancangan acak lengkap dengan faktor perbedaan jenis bahan finishing. Analisis sidik ragam menggunakan anova dan kemudian dilakukan uji beda nyata duncan. Perangkat yang digunakan adalah SPSS.19.

\section{HASIL DAN PEMBAHASAN}

2.

3.

\subsection{Hasil Pengujian Nilai Kilap, Daya Lekat, dan Fleksibelitas}

Tabel 4 berikut menyajikan nilai ratarata dari hasil pengujian daya lekat, fleksibilitas, dan nilai kilap lapisan finishing berbagai jenis bahan finishing yang diaplikasikan pada kayu lapis. Sedangkan Tabel 5 menyajikan hasil analisa sidik ragam pada pengujian daya lekat dan nilai kilap.

Nilai kilap merupakan sifat permukaan dalam memantulkan cahaya. Besarnya nilai kilap sangat dipengaruhi oleh jenis kayu, jenis bahan finishing, jumlah lapisan bahan finishing, sistem pelapisan, dan kehalusan permukaan
(Bekhta, Proszyk, Lis, \& Krystofiak, 2014; Çakicier, Korkut, \& Sevim, 2011; Salca, Krystofiak, Lis, Mazela, \& Proszyk, 2016). Pengujian nilai kilap pada permukaan kayu lapis hasil finishing menunjukkan nilai yang beragam. Nilai terendah dimiliki oleh kayu lapis dengan bahan finishing WB (53.67\%) dan nilai tertinggi terdapat pada kayu lapis dengan bahan finishing PU (74.67\%). Berdasarkan pengelompokan sebagaimana Tabel 1, maka nilai kilap NC, MM, dan WB dapat dikategorikan ke dalam kelompok semi gloss (40\% - 60\%), sedangkan nilai kilap pada lapisan finishing PU masuk ke dalam kelas gloss $(60 \%$ $80 \%$ ). Perbedaan nilai kilap tersebut disebabkan oleh adanya perbedaan jenis bahan finishing yang dapat memberikan pengaruh terhadap nilai kilap yang dihasilkan. Bahan finishing PU menghasilkan lapisan finishing yang dapat memantulkan cahaya dengan baik. Sedangkan bahan finishing WB diduga memberikan pengaruh terhadap kehalusan permukaan substrat sehingga menurunkan nilai kilap dari lapisan finishing yang terbentuk (Demirci, Sonmez, \& Budakci, 2013). Nilai kilap yang rendah pada kayu lapis dengan bahan finishing WB sejalan dengan hasil penelitian Sönmez, Budakci \& Pelit (2011) dan Salca et al. (2016).

Sejalan dengan hasil sidik ragam (Tabel 5) menunjukkan bahwa jenis bahan finishing memberikan pengaruh yang sangat signifikan pada nilai kilap, yaitu dengan nilai signifikansi 0.000 . Kemudian beberapa perlakuan bahan finishing tersebut dilakukan uji beda nyata Duncan (Tabel 4) dan hasilnya menunjukkan bahwa bahan finishing PU (nilai a) berbeda nyata dengan nilai kilap pada kayu lapis dengan bahan finishing WB, MM, dan NC, sedangkan ketiga bahan finishing tersebut saling tidak beda nyata (nilai b).

Daya lekat menunjukkan nilai kekuatan lekat bahan finishing terhadap permukaan kayu lapis. Nilai paling baik pada pengujian daya lekat tersebut dimiliki oleh kayu lapis dengan bahan finishing WB. Lapisan finishing pada kayu lapis tersebut tidak mengalami kerusakan atau dapat dikatakan lapisan finishing tersebut memiliki kualitas yang sangat bagus (nilai 
5). Hal tersebut diduga disebabkan oleh kemampuan finishing WB yang mampu Tabel 4. Hasil Pengujian Daya Lekat, Fleksibilitas, dan Nilai Kilap

\begin{tabular}{|c|c|c|c|c|}
\hline \multirow{3}{*}{$\begin{array}{l}\text { Jenis } \\
\text { finishing }\end{array}$} & \multicolumn{4}{|c|}{ Hasil penquiian } \\
\hline & \multicolumn{2}{|c|}{ Daya lekat } & \multirow{2}{*}{$\begin{array}{c}\text { Nilai } \\
\text { Fleksibelitas }\end{array}$} & \multirow{2}{*}{ Nilai kilap (\%) } \\
\hline & Kerusakan (\%) & Nilai & & \\
\hline WB & $0.00^{\mathrm{a}}$ & 5 & 5 & $53.67^{b}$ \\
\hline NC & $14.67^{b}$ & 3 & 3 & $58.67^{b}$ \\
\hline MM & $5.67^{a}$ & 3 & 3 & $57.33^{b}$ \\
\hline PU & $1.67^{\mathrm{a}}$ & 4 & 5 & $74.67^{a}$ \\
\hline
\end{tabular}

Keterangan:

a dan b: nilai dengan huruf yang sama berarti saling tidak berbeda nyata berdasarkan uji Duncan

Tabel 5. Hasil Analisa Sidik Ragam untuk Pengujian Cross Cut dan Glossy

\begin{tabular}{lcccc}
\hline Parameter & $\begin{array}{c}\text { Derajat } \\
\text { bebas }\end{array}$ & $\begin{array}{c}\text { Kuadrat } \\
\text { tengah }\end{array}$ & F.hitung & Signifikansi jenis finishing \\
\hline Cross cut & 3 & 129.00 & 13.23 & 0.002 \\
Glossy test & 3 & 259.42 & 21.03 & 0.000 \\
\hline
\end{tabular}

menembus lebih dalam pada permukaan kayu lapis dibandingkan dengan bahan finishing lainnya, sehingga WB memiliki daya lekat yang paling bagus terhadap kayu lapis. Sejalan dengan penelitian dari Hernández \& Cool (2008) dan Hazir \& Koc (2019) yang menujukkan bahwa daya lekat yang dimiliki oleh bahan finishing water based memiliki performa yang lebih bagus dibandingkan dengan bahan finishing solvent based.

Berdasarkan Tabel 4 nilai pengujian daya lekat terbaik kedua terdapat pada kayu lapis dengan bahan finishing PU dengan persentase kerusakan sebesar $1,67 \%$ atau dapat dikatakan memiliki kualitas baik (nilai 4). Sedangkan Kayu lapis dengan bahan finishing NC dan MM masuk ke dalam kelas kualitas cukup (nilai 3) dengan persentase kerusakan masingmasing adalah $14.67 \%$ dan $5.67 \%$. Sejalan dengan penelitian Dilik, Erdinler, Hazir, Koc, \& Hiziroglu (2015) yang melaporkan bahwa kekuatan rekat lapisan finishing PU pada MDF memiliki nilai yang yang paling baik jika dibandingkan dengan lapisan finishing cellulosic. Selain itu, penelitian Sulaiman et al. (2008) melaporkan bahwa hasil pengujian daya lekat pada kayu lapis dari kayu sawit dengan lapisan finishing NC dan PU memiliki nilai yang baik jika dibandingkan dengan kayu jenis Shorea sp.. Menurut
Widyorini, Khotimah, \& Prayitno (2014), nilai pengujian daya lekat yang kecil menunjukkan kekuatan rekat bahan finishing yang semakin besar. Sebaliknya semakin besar nilai hasil pengujian daya lekat, maka semakin kecil kekuatan rekat bahan finishingnya.

Berdasarkan hasil analisa sidik ragam sebagaimana disajikan pada Tabel 5, menunjukkan bahwa jenis bahan finishing juga memberikan pengaruh yang nyata terhadap hasil pengujian daya lekat, yaitu dengan nilai signifikansi 0.002 . Kemudian beberapa perlakuan bahan finishing tersebut dilakukan uji beda nyata Duncan (Tabel 4) dan hasilnya menunjukkan bahwa kayu lapis dengan bahan finishing NC memiliki nilai yang berbeda nyata (nilai b) dengan kayu lapis dengan bahan finishing lainnya. Sedangkan kayu lapis dengan bahan finishing WB, PU, dan MM menunjukkan saling tidak berbeda nyata (nilai a).

Pengujian fleksibilitas dilakukan untuk mengetahui kegetasan suatu bahan finishing terhadap substrat ataupun lapisan cat di bawahnya (Prayitno et al., 2013) . Hasil pengujian fleksibilitas pada kayu lapis dengan bahan finishing yang berbeda dapat dikelompokkan menjadi dua jenis. Untuk kayu lapis dengan bahan finishing WB dan PU menunjukkan hasil yang sangat baik, yaitu setelah dilakukan 


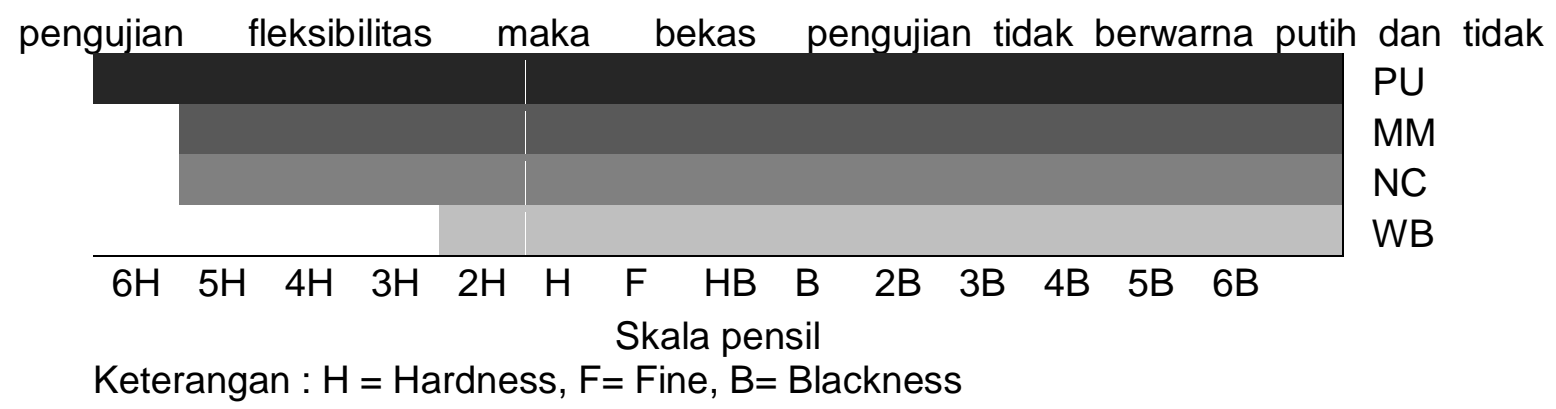

\section{Gambar 1. Hasil Pengujian Pencil Hardness}

berbunyi getas sewaktu digores. Hal tersebut menunjukkan kualitas finishing memiliki fleksibilitas yang sangat baik. Sedangkan kayu lapis dengan bahan finishing NC serta MM menunjukkan nilai yang cukup. Hal ini berarti bahwa kayu lapis dengan bahan finishing $\mathrm{NC}$ serta MM setelah dilakukan pengujian akan menimbulkan sedikit warna putih dan cukup berbunyi saat digores. Sejalan dengan penelitian sebelumnya bahwa bahan finishing WB yang diaplikasikan pada kayu jati menghasilkan kualitas baik sampai dengan sangat baik setelah diuji fleksibilitas (Prayitno et al., 2013).

\section{2.}

\section{3.}

\subsection{Hasil Pengujian Kekerasan}

Pengujian kekerasan dengan metode pencil hardness merupakan pengujian untuk mengetahui kekerasan lapisan finishing yang banyak digunakan oleh industri. Hasil pengujian kekerasan ditampilkan pada Gambar 1. Kayu lapis dengan bahan finishing PU memiliki tingkat kekerasan yang paling tinggi $(6 \mathrm{H})$ diikuti oleh kayu lapis dengan bahan finishing MM dan NC $(5 \mathrm{H})$. Sementara itu nilai pengujian terendah terdapat pada kayu lapis dengan bahan finishing WB. Hal ini menunjukkan bahwa lapisan finishing yang dihasilkan oleh bahan finishing WB adalah yang paling lunak jika dibandingkan dengan bahan finishing lainnya. Sejalan dengan penelitian Çakicier et al. (2011) yang menunjukkan bahwa tingkat kekerasan lapisan finishing solvent based (NC dan $\mathrm{PU})$ lebih tinggi dibandingkan tingkat kekerasan lapisan finishing WB. Penelitian lainnya juga telah melaporkan bahwa nilai kekerasan lapisan finishing PU yang diaplikasikan pada MDF memiliki nilai kekerasan yang lebih bagus dibandingkan dengan lapisan finishing cellulosic (Erdinler, Koc, Dilik, \& Hazir, 2019). Kekerasan lapisan finishing dipengaruhi oleh jenis bahan finishing yang digunakan, selain itu juga sangat dipengaruhi oleh substrat yang digunakan (Choi \& Kim, 2006). Hasil penelitian ini menunjukkan bahwa berdasarkan tingkat kekerasannya, keempat jenis bahan finishing terklasifikasi menjadi tiga kategori, yaitu sangat bagus (PU), bagus (MM \& NC), dan sedang (WB) (ATFA, 2018)

\subsection{Hasil Pengujian Ketahanan terhadap Panas-Dingin dan Bahan Kimia Rumah Tangga}

Pengujian ketahanan lapisan finishing terhadap panas dan dingin serta bahan kimia rumah tangga kecap dan saos disajikan pada Tabel 6. Pengujian ini sangat diperlukan untuk mengetahui ketahanan lapisan finishing pada suatu produk yang akan digunakan pada lingkungan panas-dingin atau yang akan sering berinteraksi dengan bahan kimia rumah tangga. Sejalan dengan Kaygin \& Akgun (2008) yang menyatakan bahwa untuk mengetahui ketahanan finishing jangka panjang seperti terkait efek mekanis (gesekan, abrasi, dan benturan) dan efek kimiawi (asam, alkali, deterjen, dan alkohol) maka diperlukan pengujian sesuai dengan area penggunaannya. Hasil pengujian pada Tabel 6 menunjukkan bahwa untuk semua kayu lapis yang diberi perlakuan bahan finishing berbeda memiliki nilai ketahanan lapisan finishing yang sama, yaitu kesemuanya dapat 
dikelompokkan ke dalam kelas 10 . Hal ini menunjukkan bahwa semua bahan finishing yang digunakan pada penelitian Tabel 6. Hasil Pengujian Ketahanan Lapisan Finishing terhadap Panas-Dingin dan Bahan Kimia Rumah Tangga

\begin{tabular}{lllll}
\hline \multirow{2}{*}{$\begin{array}{l}\text { Jenis } \\
\text { Bahan } \\
\text { finishing }\end{array}$} & \multicolumn{2}{l}{$\begin{array}{l}\text { Ketahanan terhadap } \\
\text { panas-dingin }\end{array}$} & \multicolumn{2}{l}{$\begin{array}{l}\text { Ketahanan terhadap bahan kimia rumah } \\
\text { tangga }\end{array}$} \\
\cline { 2 - 5 } & Air panas & Air dingin & Saos & Kecap \\
\hline WB & 10 & 10 & 10 & 10 \\
NC & 10 & 10 & 10 & 10 \\
MM & 10 & 10 & 10 & 10 \\
PU & 10 & 10 & 10 & 10 \\
\hline
\end{tabular}

ini memiliki nilai ketahanan yang sangat bagus, yaitu tidak menimbulkan kerusakan ataupun perubahan warna pada lapisan finishing. Kerusakan lapisan finishing terjadi apabila suatu zat kimia tertentu merusak struktur lapisan bahan finishing pada permukaan substrat sehingga lapisan bahan finishing menjadi rusak atau berubah warna.

\section{KESIMPULAN DAN SARAN}

Berdasarkan pengujian nilai kilap, lapisan finishing WB, NC, dan MM masingmasing memiliki nilai kilap 53.67\%, $57.33 \%$, dan $58.67 \%$. Ketiga nilai kilap tersebut dapat dikelompokkan dalam kelas semi gloss (40-60)\%. Sedangkan nilai kilap lapisan finishing PU, yaitu sebesar $74.67 \%$ termasuk ke dalam kelas gloss $(60-80) \%$. Hasil pengujian daya lekat menunjukkan bahwa lapisan finishing WB memiliki kekuatan lekat yang paling tinggi (kelas 5) diikuti lapisan finishing PU (kelas 4) dan finishing $\mathrm{MM}$ serta NC (kelas 3). Berdasarkan pengujian fleksibilitas menunjukkan bahwa lapisan finishing WB dan PU memiliki fleksibilitas sangat baik sedangkan NC dan MM termasuk kategori cukup. Kemudian berdasarkan kekerasannya, maka lapisan finishing PU memiliki tingkat kekerasan yang paling tinggi $(6 \mathrm{H})$ diikuti lapisan finishing MM dan NC $(5 \mathrm{H})$. Sedangkan kekerasan lapisan finishing WB termasuk yang paling rendah yaitu $2 \mathrm{H}$. Hasil pengujian ketahanan lapisan finishing terhadap panas-dingin dan bahan kimia rumah tangga menunjukkan hasil yang sama untuk semua lapisan finishing, yaitu dapat dikelompokkan ke dalam kelas 10. Dilihat dari nilai kilap, daya lekat, fleksibilitas, kekerasan, dan ketahanan terhadap panas dingin serta bahan kimia rumah tangga, maka secara umum bahan finishing yang memiliki performa paling bagus diaplikasikan pada kayu lapis adalah jenis PU.

\section{DAFTAR PUSTAKA}

American Society for Testing and Materials (ASTM). (2000). Standard Test Methods for Evaluation of Painted or Coated Speciment Subject to Corrosive Environments ASTM D 1654-92. West Conshohocken, PA, USA: American Society for Testing and Materials

American Society for Testing and Materials (ASTM). (2000). Standard Test Methods for Film Hardness by Pencil Test ASTM D 3363-0. West Conshohocken, PA, USA: American Society for Testing and Materials

American Society for Testing and Materials (ASTM). (2000). Standard Test Methods for Measuring Adhesion by Tape Test ASTM D 3359-02. West Conshohocken, PA, USA: American Society for Testing and Materials

Australasian Timber Flooring Association (ATFA). (2018). Assessing the hardness of coatings. Australasian Timber Flooring Association Ltd, 1-3. https://www.atfa.com.au/wpcontent/uploads/2019/01/86_Assessin g-the-hardness-of-coating.pdf

Badan Pusat Statistik (BPS). (2018). Statistik Produksi Kehutanan 2017. Indonesia: Badan Pusat Statistik. 
Bekhta, P., Proszyk, S., Lis, B., \& Krystofiak, T. (2014). Gloss of thermally densified alder (Alnus glutinosa Goertn.), beech (Fagus sylvatica L.), birch (Betula verrucosa Ehrh.), and pine (Pinus sylvestris L.) wood veneers. European Journal of Wood and Wood Products, 72(6), 799-808.

https://doi.org/10.1007/s00107-0140843-3

Bioindustries. (2017). Mengenal istilah tingkat glossy berdasarkan sheen level versi Bioindustries. Retrieved from Bioindustries website: https://www.bioindustries.co.id/menge nal-istilah-tingkat-glossy-

7243.htmIBioindustries.

Çakicier, N., Korkut, S., \& Sevim, K. D. (2011). Varnish layer hardness, scratch resistance, and glossiness of various wood species as affected by heat treatment. BioResources, 6(2), 1648-1658.

https://doi.org/10.15376/biores.6.2.16 48-1658

Choi, J. H., \& Kim, H. J. (2006). Three hardness test methods and their relationship on UV-curable epoxy acrylate coatings for wooden flooring systems. Journal of Industrial and Engineering Chemistry, 12(3), 412417.

Demirci, Z., Sönmez, A., \& Budakçi, M. (2013). Effect of thermal ageing on the gloss and the adhesion strength of the wood varnish layers. BioResources, $8(2)$, 1852-1867. https://doi.org/10.15376/biores.8.2.18 52-1867

Dilik, T., Erdinler, S., Hazir, E., Koç, H., \& Hiziroglu, S. (2015). Adhesion strength of wood based composites coated with cellulosic and polyurethane paints. Advances in Materials Science and Engineering, 2015(June).

https://doi.org/10.1155/2015/745675

Erdinler, E. S., Koc, K. H., Dilik, T., \& Hazir, E. (2019). Layer thickness performances of coatings on MDF: Polyurethane and cellulosic paints. Maderas: Ciencia y Tecnologia, 21(3),
317-326.

https://doi.org/10.4067/S0718221X2019005000304

Hazir, E., \& Koc, K. H. (2019). Evaluation of wood surface coating performance using water based, solvent based and powder coating. Maderas: Ciencia y Tecnologia, 21(4), 467-480. https://doi.org/10.4067/s0718$221 \times 2019005000404$

Hernández, R. E., \& Cool, J. (2008). Evaluation of three surfacing methods on paper birch wood in relation to water and solvent-borne coating performance. Wood and Fiber Science, 40(3), 459-469.

Kaygin, B., \& Akgun, E. (2008). A nanotechnological product: An innovative varnish type for wooden surfaces. Scientific Research and Essays, 4(1), 001-007.

Munadi, E., \& Salim, Z. (2017). Info komoditi furnitur. Bunga Rampai Info Komoditi Furnitur, 1-6. a_content/2017/10/Isi_BRIK_FURNIT UR.pdf

Prayitno, T. A., Ayu, R., \& Sari, M. (2013). Sifat finishing kayu jati setelah perlakuan panas. Prosiding Seminar Nasional Masyarakat Peneliti Kayu Indonesia (MAPEKI) XVI (pp. 75-82).

Purwanto, D. (2011). Finishing kayu kelapa (Cocos Nucifera, L) untuk bahan interior ruangan. Jurnal Riset Industri Hasil Hutan, 3(2), 32-37.

Ramananantoandro, T., Eyma, F., Belloncle, C., Rincé, S., \& Irle, M. (2018). Effects of machining parameters on raised grain occurring after the application of water-based finishes. European Journal of Wood and Wood Products, 76(4), 13231333. https://doi.org/10.1007/s00107017-1250-3

Salca, E. A., Krystofiak, T., \& Lis, B. (2017). Evaluation of selected properties of alderwood as functions of sanding and coating. Coatings, $7(10)$. https://doi.org/10.3390/coatings71001 76

Salca, E. A., Krystofiak, T., Lis, B., Mazela, B., \& Proszyk, S. (2016). Some 
coating properties of black alder wood as a function of varnish type and application method. BioResources, 11(3), 7580-7594. https://doi.org/10.15376/biores.11.3.7 580-7594

Sönmez, A., Budakçi, M., \& Pelit, H. (2011). The effect of the moisture content of wood on the layer performance of water-borne varnishes. BioResources, 6(3), 31663177.

https://doi.org/10.15376/biores.6.3.31 66-3177

Sulaiman, O., Hashim, R., Wahab, R., Samsi, H. W., \& Mohamed, A. H. (2008). Bewertung der Oberflächeneigenschaften von Unterschiedlich Behandeltem Ölpalmen-sperrholz. Holz Als Roh Und Werkstoff, 66(1), 5-10. https://doi.org/10.1007/s00107-0070194-4

Véronic, L., Blanchet, P., \& Cormier, L. M. (2013). Water-based and solventbased stains: Impact on the grain raising in yellow birch. BioResources, $8(2)$, 1997-2009. https://doi.org/10.15376/biores.8.2.19 97-2009

Widyorini, R., Khotimah, K., \& Prayitno, T. (2014). Pengaruh suhu dan metode perlakuan panas terhadap sifat fisika dan kualitas finishing kayu mahoni. Jurnal IImu Kehutanan, 8(2), 65-74. https://doi.org/10.22146/jik.10160 